Sādhanā, Vol. 18, Part 6, December 1993, pp. 999-1008. (C) Printed in India.

\title{
Aquifer recharge by seepage losses from canals
}

\author{
NHRAO \\ Water Technology Centre, Indian Agricultural Research Institute, New \\ Delhi 110012, India \\ MS received 17 June 1991; revised 7 May 1993
}

\begin{abstract}
The effects of subsurface conditions on recharge of leaky aquifers by seepage from irrigation canals are examined. The rate of recharge depends on the vertical rates of flow into the aquifer. The physical and geological data along a lithological section of the Mahi Right Bank Canal Command Area in Gujarat are used. At the same location, seepage losses can vary by a factor of seven depending on the position of the water table. For a specified water table depth, the seepage flows vary significantly with the depth to the aquifer. But their vertical components, which are responsible for aquifer recharge, do not show such significant variation with the depth to the aquifer.
\end{abstract}

Keywords. Aquifer; recharge; canal; seepage losses.

\section{Introduction}

In India, canal irrigation by major and medium irrigation projects accounts for about 30 million hectares of irrigated area. Groundwater was the main source of irrigation in many areas prior to the introduction of canal irrigation. It continues to be so in several major irrigation project areas even though this factor was not explicitly considered in their design and operation. However, in recent years, there is more emphasis on groundwater development in canal irrigation projects and for planned conjunctive use of canal water and groundwater to augment canal supplies and control waterlogging and soil salinity (Govt. of India 1985).

Many large irrigation schemes are constructed on rivers and the underlying aquifers are alluvial. Such aquifers consist of bands of gravel, sand, silt and clay. The bands are not continuous and the clay layers contain some sand and the sand layers some silt and clay. Shallow tube wells and dug wells are the major means of abstracting water from these aquifers. The wells tap the aquifers through several confined zones of more permeable sand and gravel bands (figure 1). The exploitation of such aquifers for conjunctive use with canal water will, therefore, depend on the extent by which these zones are recharged.

Seepage from the water conveyance and distribution network of the canal irrigation system is a principle source of aquifer recharge. The recharge occurs first at the 


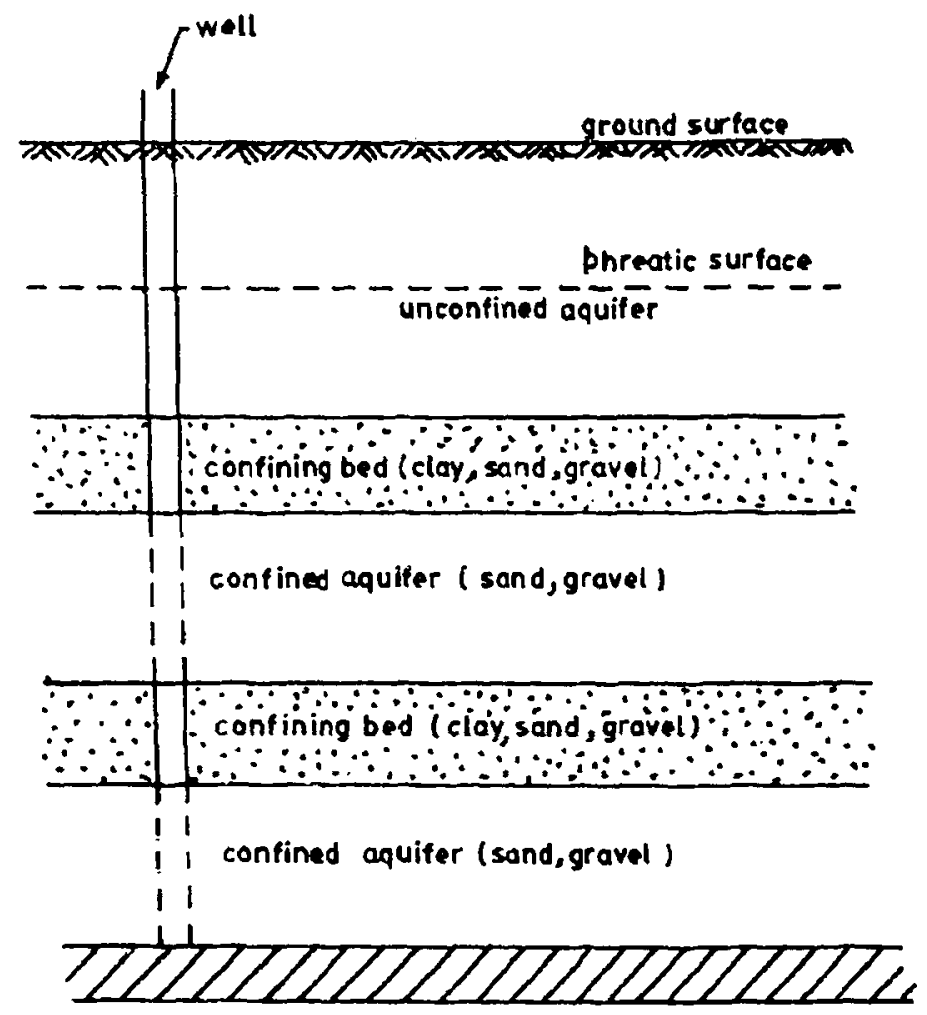

Figure 1. Schematic cross-section of an alluvial aquifer.

phreatic surface and moves down to the more permeable zones tapped by the wells. Rapid movement of water to these zones is governed by the permeability of the zones between the ground surface and the confined aquifer and the depth of the water table when recharge occurs at the ground surface. The key to efficient exploitation of the aquifers through conjunctive use schemes in irrigation projects lies, therefore, in recognizing that the actual recharge of the aquifers cannot exceed the vertical rates of flow between the phreatic surface and the aquifer.

However, conventional methods of estimating groundwater potential in irrigation projects for planning conjunctive use schemes ignore the complex interactions between surface and ground water systems (Govt. of Gujarat 1975). For example, the recharge of aquifers resulting from canal seepage is considered to depend only on the wetted perimeter within the canal. No account is taken of the aquifer into which recharge is occurring. The difficulties with the use of such methods have been discussed in detail by Wachyan \& Rushton (1987).

Bouwer (1969, pp. 121-172) showed that seepage losses depend primarily on the hydraulic conductivity of the aquifer and the type of boundaries of the system within which the flow is occurring. He derived numerical solutions and obtained a series of design curves. More recently, Wachyan \& Rushton (1987) solved a hypothetical seepage now problem by considering an intermediate layer of low hydraulic conductivity between the canal surface and the aquifer. This condition is more representative of the subsurface lithology in alluvial aquifers.

This study extends the work of Wachyan \& Rushton (1987) to the inclusion of actual subsurface conditions occurring in a major irrigation project. The aquifer conditions occurring in the Mahi Right Bank Canal (MRBC) Project in Gujarat along the Cambay-Thasra lithological section (figure 2) are used to specify the 


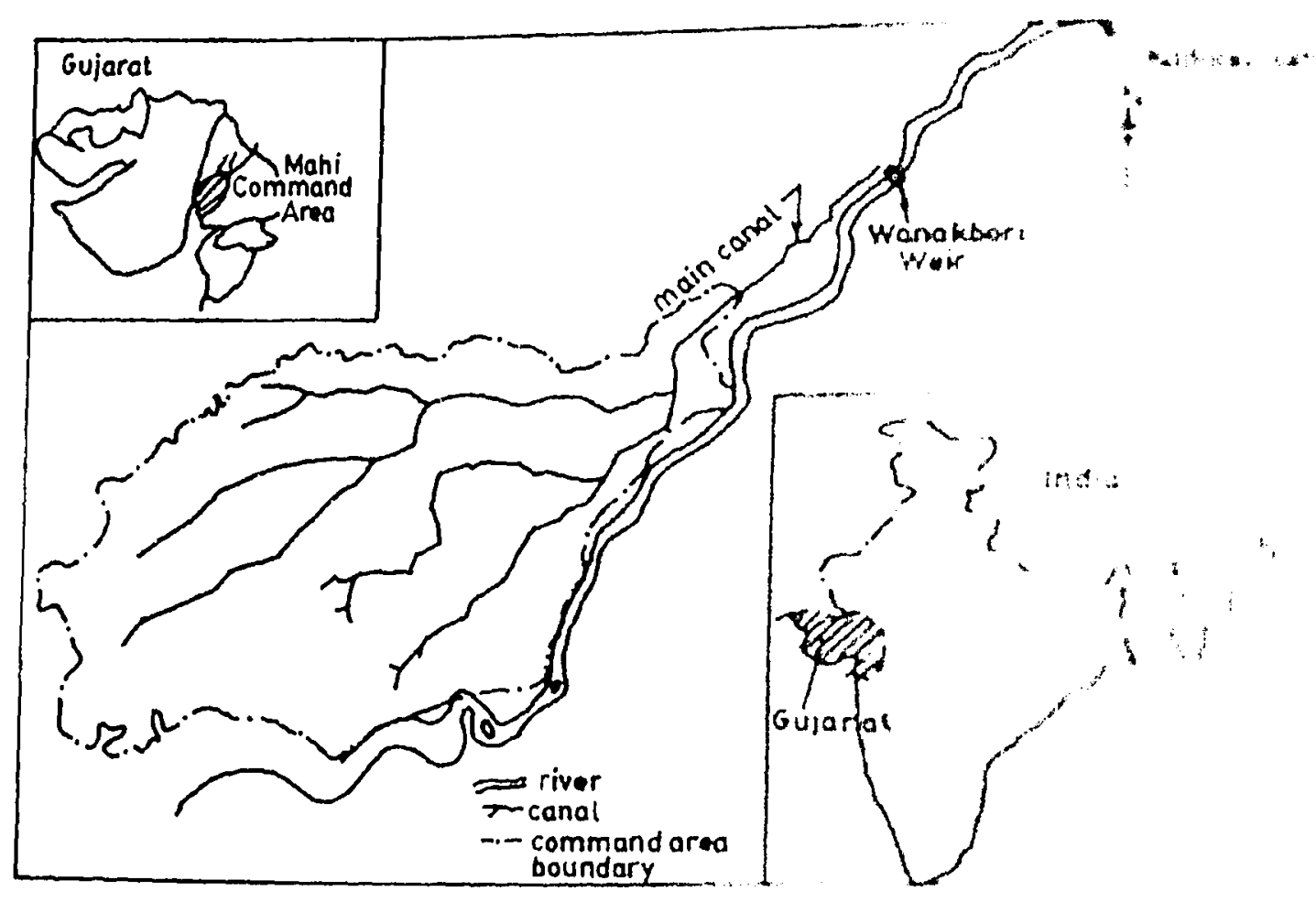

Figure 2. The Mahi Right Bamh ( ma! 1 .

subsurface conditions influencing the recharge preses, 1.5 ? irrigation project is given elsewhere (Water Techmiliny $1 \ldots$ 1988; Sondhi et al 1989).

\subsection{Aquifer conditions}

The main water bearing formations consist of alluvial (leptril a fa, e

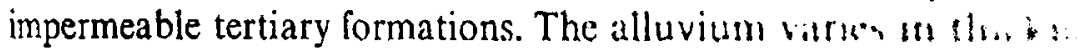
in the north-east to more than $300 \mathrm{~m}$ in the west. If wim! clay which are mixed but within the alluvial depustr !l. : 1.

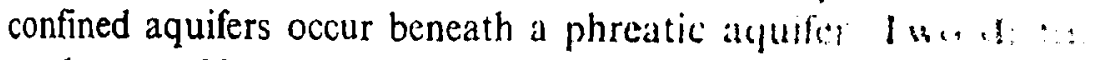
one between 20 to $50 \mathrm{~m}$ depth and the other between $41,(1,1,1, \ldots \ldots+$;

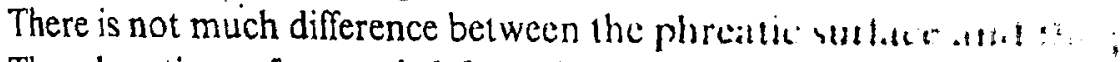

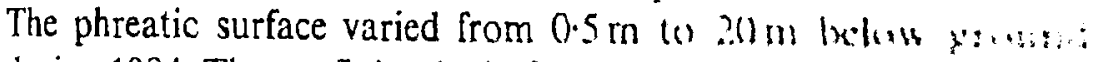
during 1984. The confining bed of the aquifers is icats ant a...:

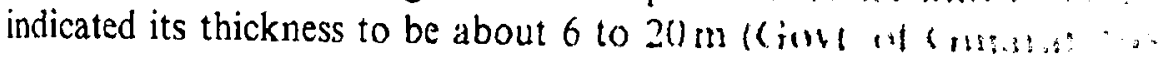

\section{Problem formulation}

This study deals with the determination of seepage lowsen $1, \ldots 1:, \ldots, \ldots$ rates of now into the upper aquifer. The subsurfice sinfuntu.

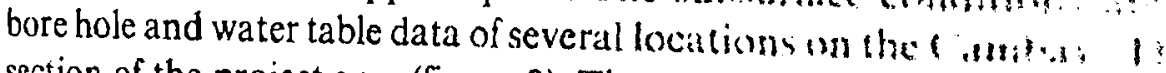
section of the project area (figure 3). The main and brask h a mas

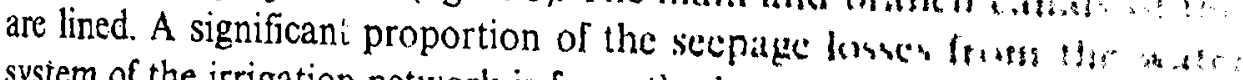
system of the irrigation network is from the large numbet w 1 1 from the main and branch canals. To investigatte the eflec is it 


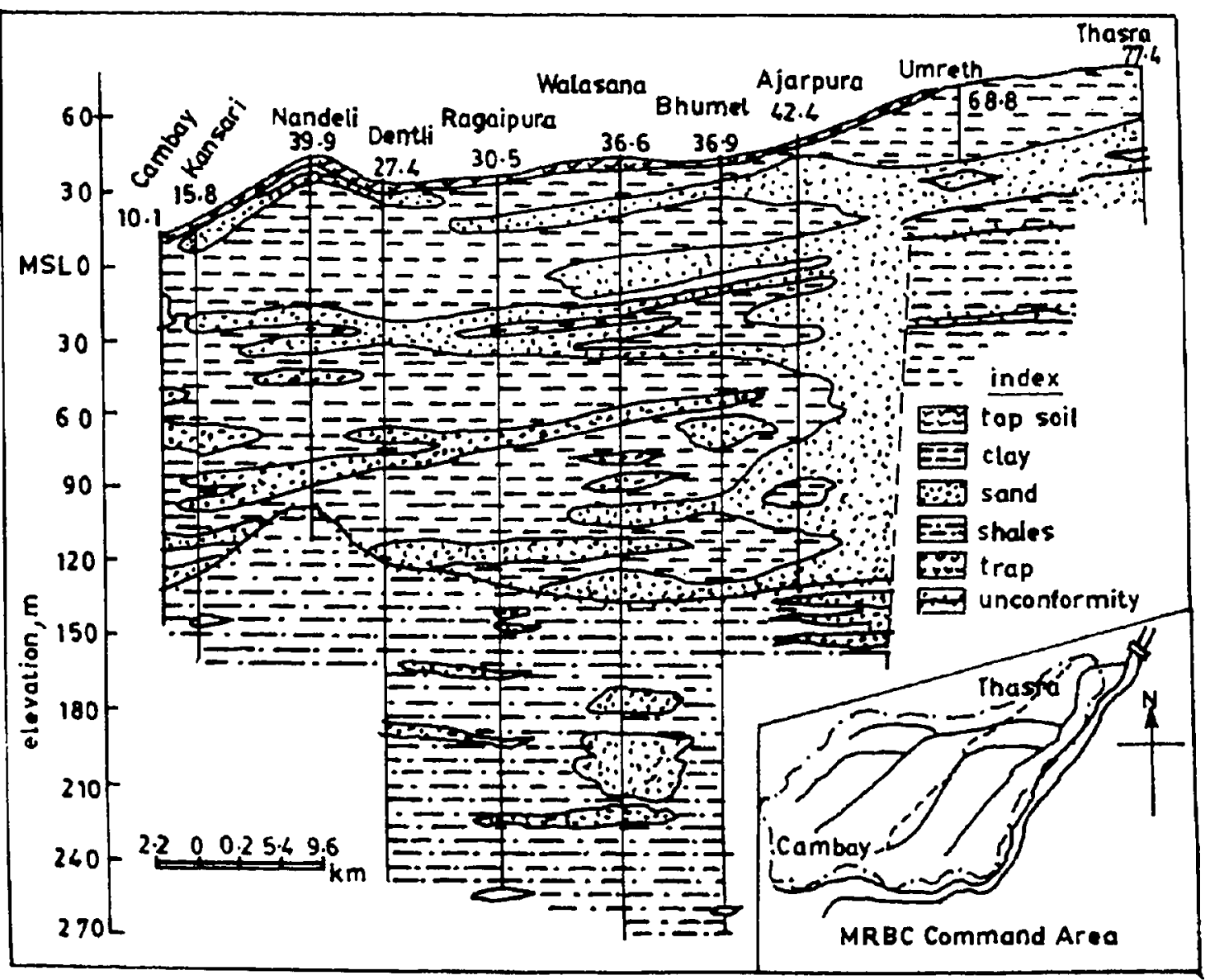

Figure 3. Lithological cross-section across Cambay and Thasra.

which determine the recharge to the leaky aquifers by seepage from the distributaries, a standard canal of bed width $3 \mathrm{~m}$, side slopes $1: 1$, and depth of flow $1 \mathrm{~m}$ is considered. These dimensions approximate those of the Sansad distributary which takes off from the Cambay branch canal (Water Technology Centre 1983).

The subsurface conditions at five locations on the Cambay-Thasra section are given in table 1. Representative values of horizontal $\left(K_{x}\right)$ and vertical $\left(K_{z}\right)$ permeabilities for the sandy clay layers occurring between the ground surface and the aquifer are taken to be $1 \mathrm{~m} /$ day. These values for any intermediate sand layers are $5 \mathrm{~m} / \mathrm{day}$. For the less permeable leakly layer above the confined aquifer, the thickness is assumed

Table 1. Depth to aquifer, observed variation in water table depth and thickness and location of sandy layers at five locations on the Cambay-Thasra section in the Mahi Right Bank Canal project.

\begin{tabular}{lccc}
\hline Location & $\begin{array}{c}\text { Depth to } \\
\text { aquifer }(H) \\
(\mathrm{m})\end{array}$ & $\begin{array}{c}\text { Water table } \\
\text { depth }(D) \\
(\mathrm{m})\end{array}$ & $\begin{array}{c}\text { Thickness and } \\
\text { location of sandy } \\
\text { layer }\end{array}$ \\
\hline Cambay & 22 & $6-12$ & - \\
Nandeli & 60 & $6-12$ & $2 \mathrm{~m}$; at 4 m depth \\
Dentli & 55 & $6-19$ & $2 \mathrm{~m}$; below top soil \\
Walasana & 15 & $3-6$ & - \\
Ajarpura & 36 & $3-6$ & - \\
\hline
\end{tabular}




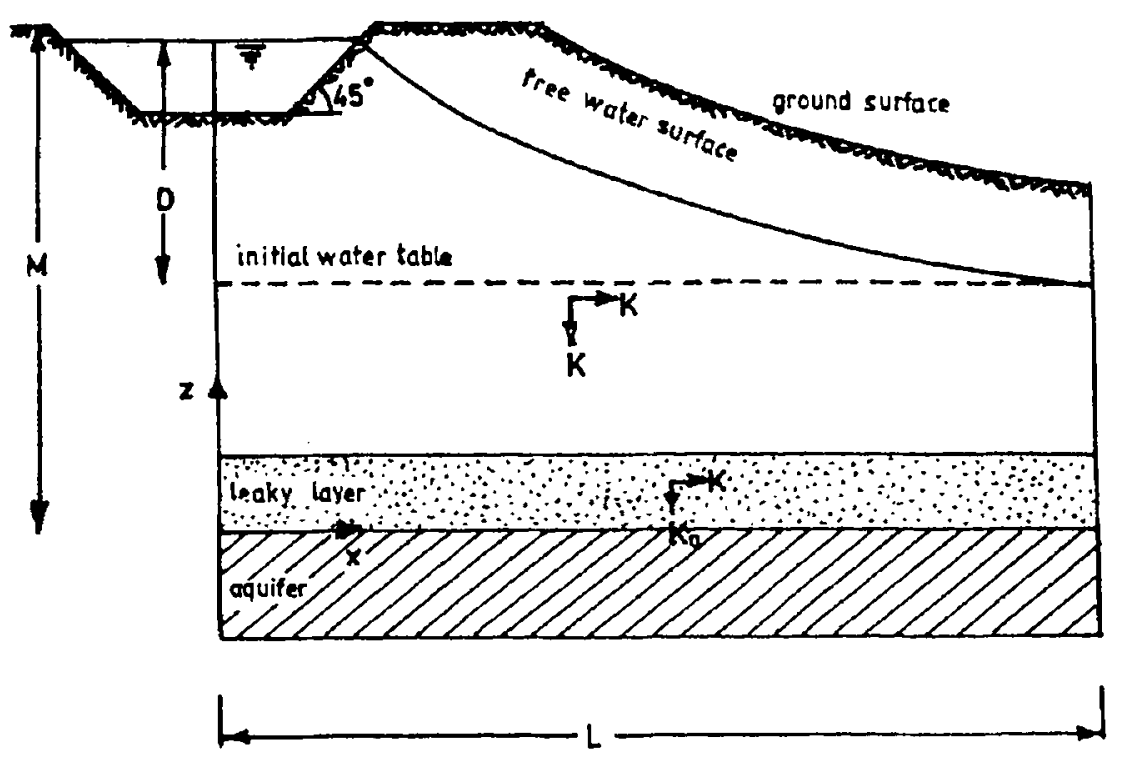

Figure 4. Conceptual model of the now system.

to be $6 \mathrm{~m}$. Its vertical and horizontal permeabilities are assumed to be 0.005 and $0.05 \mathrm{~m} /$ day respectively (Rushton 1989).

The dimensions of the flow system are shown in figure 4. All measurements shown in the figure are with respect to the centre of the canal as the origin. Constant head boundaries are assumed at a distance $L$ metres from the centre of the canal on either side. This represents the distance beyond which seepage losses from the canal will cease to influence the position of the water table. Alternately, the boundaries can be at a distance $L$ metres from the canal centre on either side. Because of flow symmetry only one half of the flow system is shown in the figure.

The total seepage flow from the canal can be partitioned into flows in the horizontal and vertical directions. The horizontal flows exit from the flow system of figure 4 at the boundary $L$ metres away from the canal centre. Only the vertical component of the seepage flow recharges the aquifer through the leaky layer.

The heads inside the canal are zero. The heads on the lower boundary are specified by the depth to the water table $(-D)$. A seepage face is present at the outer boundary at $x=L$. The equation of steady state groundwater flow for the flow system of figure 4 is given by:

$$
\frac{\partial}{\partial x}\left(K_{x} \frac{\partial h}{\partial x}\right)+\frac{\partial}{\partial z}\left(K_{z} \frac{\partial h}{\partial z}\right)=0 .
$$

The boundary conditions are given by

$$
\begin{aligned}
h & =0, \\
h(x,-M) & =-\mathrm{D}, \\
h(L, z) & =-D ; \quad z<-D, \\
& =z ; \quad z>-D .
\end{aligned}
$$

In addition, one boundary is the free surface. The position of the free surface is not known a priori. It is determined iteratively by trial and error using two conditions 
that need to be satisfied simultaneously at the free surface boundary. The first condition is that the pressure is atmospheric at the free surface and the second is that no flow crosses this boundary.

Thus, at the free surface boundary

and

$$
h(x, z)=z,
$$

$$
(\partial h / \partial n)=0 \text {. }
$$

The procedure described by Rushton \& Redshaw (1979) is used to determine the position of the free surface by systematic trial and error such that (5) and (6) are satisfied at this surface.

\section{Numerical solution}

For the specified flow conditions, the equations of two-dimensional groundwater flow are solved numerically at each of the five locations listed in table 1 . Solutions to the finite difference equations were obtained by the successive over-relaxation (SOR) method (Rushton \& Redshaw 1979). A two-dimensional non-uniform rectangular grid is used to set up the finite difference equations at each location (figure 5). The spacing between nodes increases in both horizontal and vertical directions with distance from centre of the canal. The computer programs used are a development of the routines described by Rushton \& Redshaw (1979). To determine the position of the free surface, the flow equations are solved iteratively till convergence is achieved for the free surface. The computer program may occasionally fail to find the correct free surface position. Running the program again with more mesh divisions in the vertical direction usually overcomes this problem.

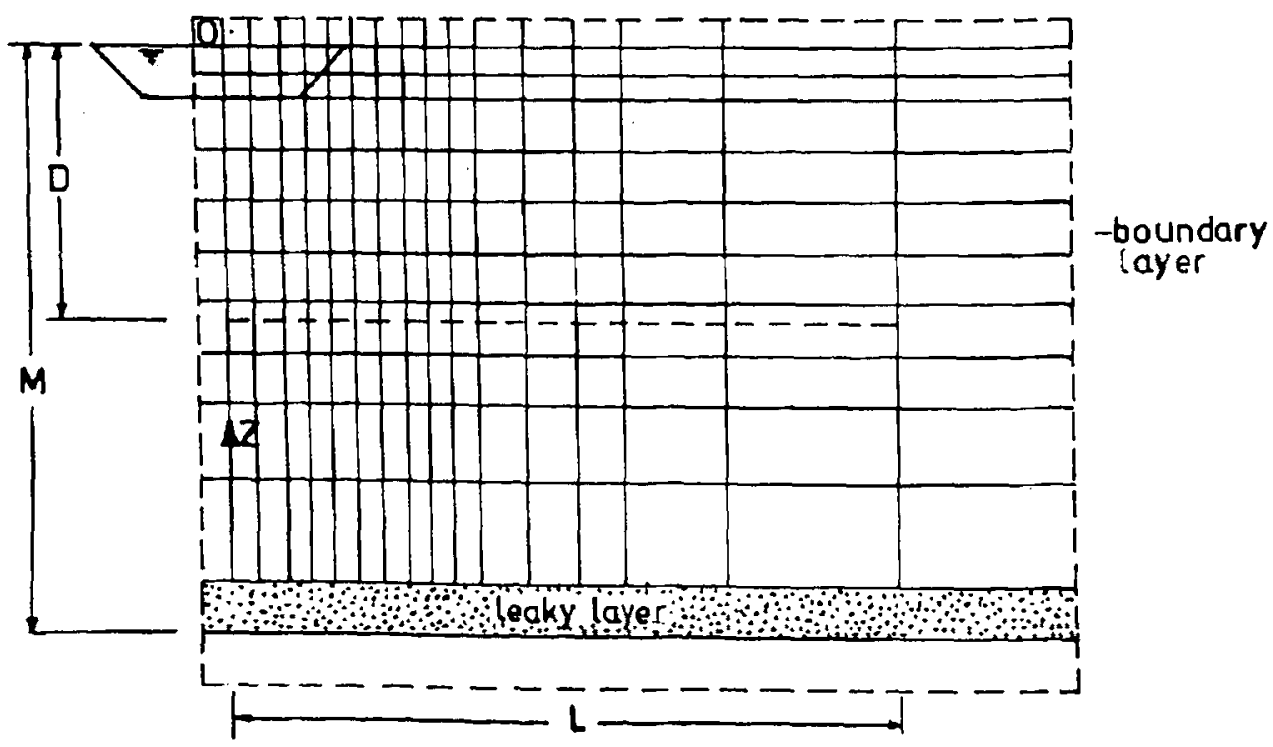

Figure 5. Non-uniform grid used to solve the equation by the finite ditierence method. 
Table 2. Steady state seepage losses at four locations on the Cambay-Thasra section of the Mahi Right Bank Canal Project (initial water table depth $=6.0 \mathrm{~m}$ ).

\begin{tabular}{lcccc}
\hline & Depth to & \multicolumn{3}{c}{ Seepage losses $\left(\mathrm{m}^{3} /\right.$ day) } \\
\cline { 5 - 5 } & $\begin{array}{c}\text { aquifer } \\
(\mathrm{m})\end{array}$ & $\begin{array}{c}\text { Outflow at } \\
\text { boundary }\end{array}$ & $\begin{array}{c}\text { Vertical flow } \\
\text { into aquifer }\end{array}$ & Total \\
\hline Walasana & 15 & 0.14 & 0.42 & 0.56 \\
Cambay & 22 & 0.35 & 0.43 & 0.78 \\
Ajarpura & 36 & 0.70 & 0.40 & 1.10 \\
Dentii & 55 & 0.93 & 0.33 & 1.26 \\
Nandeli & 60 & 1.01 & 0.32 & 1.33 \\
\hline
\end{tabular}

\section{Results}

\subsection{Seepage losses at different locations}

Detailed results of the numerical simulations are presented for the five locations listed in table 1. These represent shallow to deep aquifers in the Cambay Thasra section.

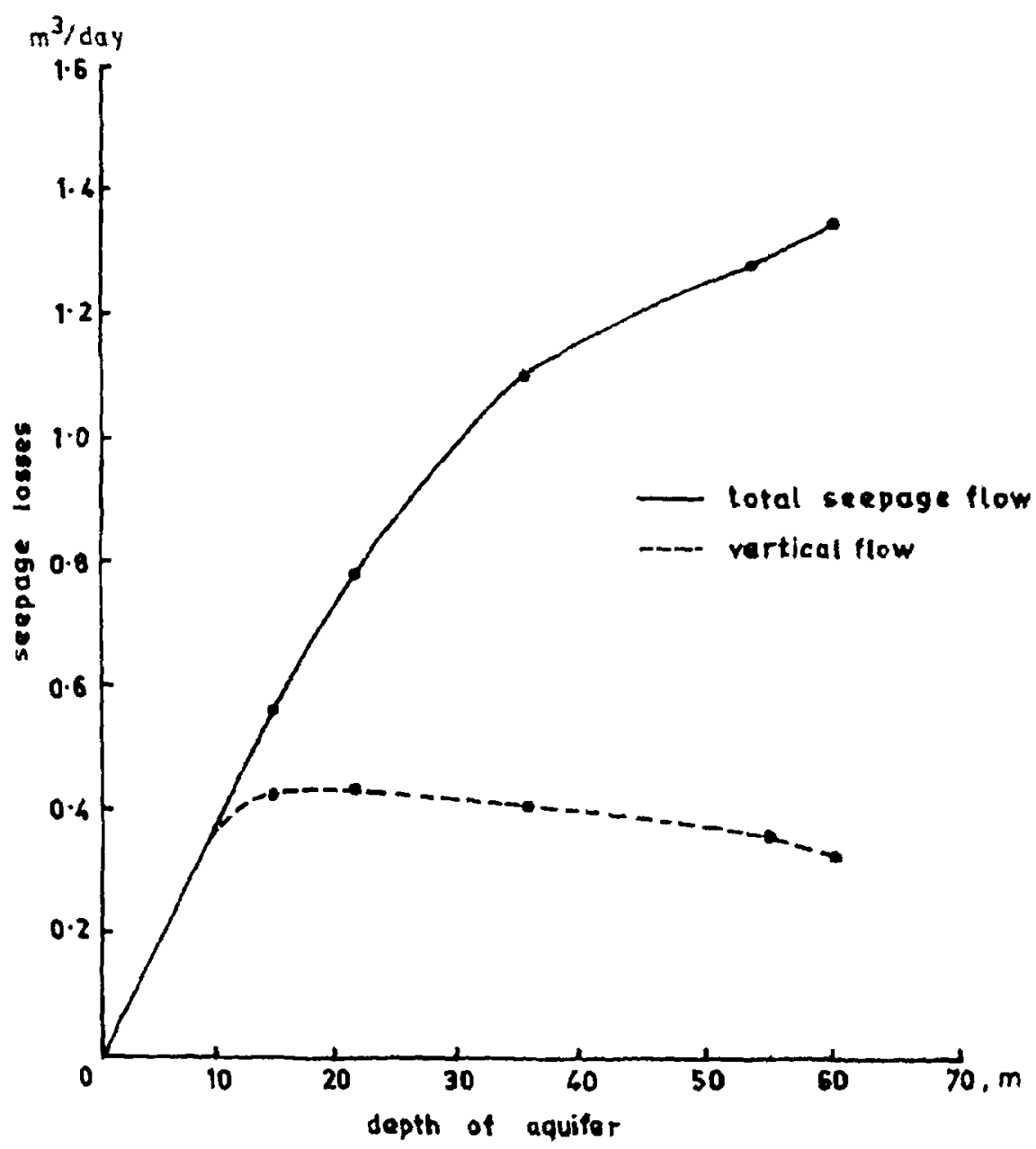

Figure 6. Variation of seepage flows with aquifer depth on the Cambay-Thasra lithological section in the MRBC area. 
The seepage losses per unit length of canal at the five locations were first calculated with the water table at a distance of $6.0 \mathrm{~m}$ and $L=200 \mathrm{~m}$. The results are summarized in table 2. As the depth to the aquifer increases, seepage losses also increase. But an increasing proportion of the seepage losses appears as outflow at the boundary $(x=L)$. The vertical component of the seepage flows, which recharges the aquifer, is actually slightly reduced with increasing depth to the aquifer (figure 6). The seepage rates vary from about $0.6 \mathrm{~m}^{3} /$ day to $1.5 \mathrm{~m}^{3} /$ day. These values compare with a constant rate of $1 \cdot 1 \mathrm{~m}^{3} /$ day obtained for canals of the above size by applying the standard norms of the Central Ground Water Board (1985).

\subsection{Effect of water table position}

This was determined for two locations, Cambay and Ajarpura (table 1). The seepage losses per unit length of canal increased with depth to the water table. The losses were significantly more for the deeper aquifer at Ajarpura. However, the vertical component of flow reacharging the aquifer is higher for the shallow aquifer at Cambay (figure 7). The recharge rate varies from $0.4 \mathrm{~m}^{3} /$ day for the initial water table at $6.0 \mathrm{~m}$, to $0.9 \mathrm{~m}^{3} /$ day for the water table at $12 \mathrm{~m}$ at Cambay. Thus, there is more than a two-fold increase in the rate of recharge over the observed (table 1) range of water table elevation at this location.

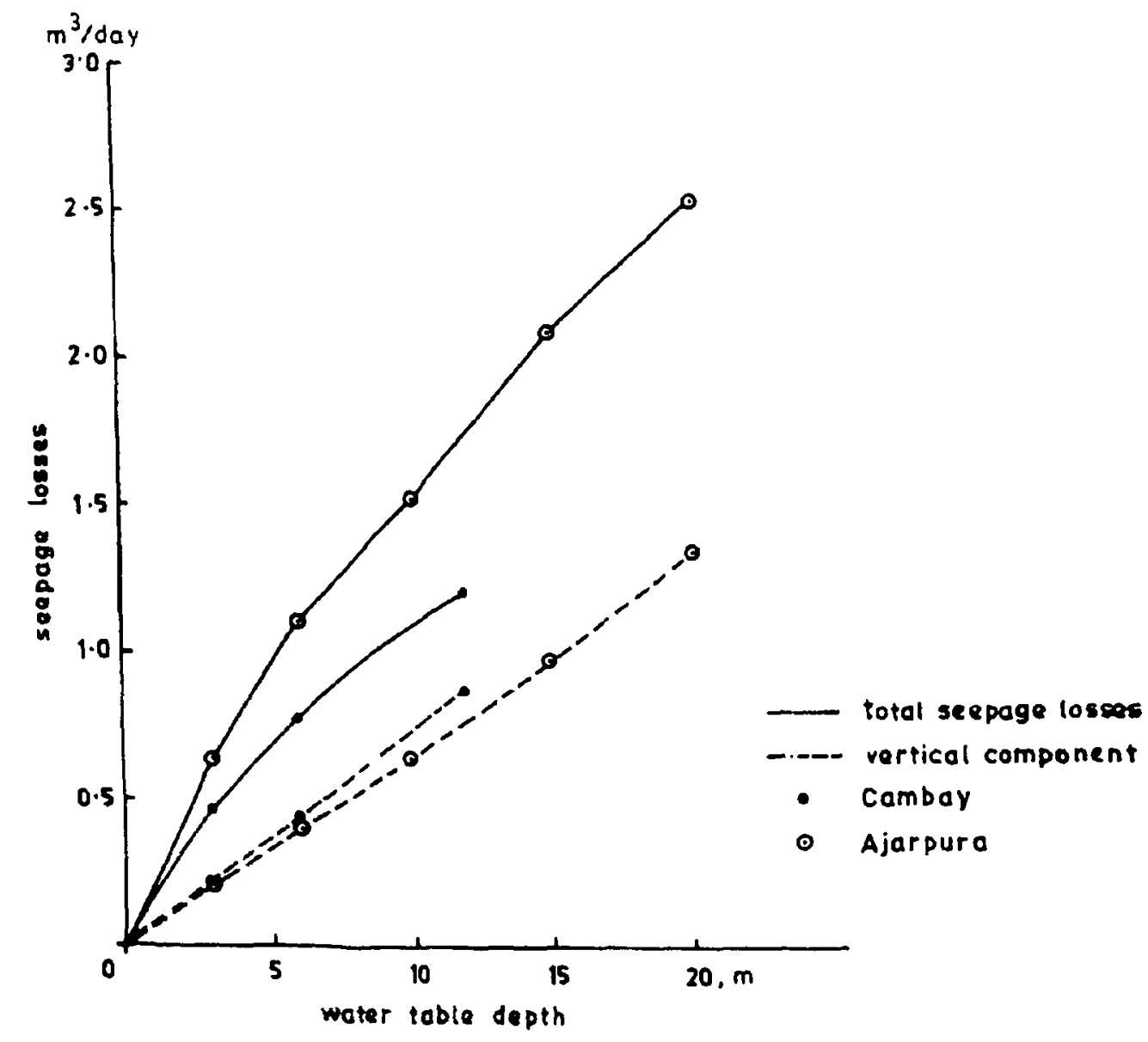

Figure 7. Total seepage losses and vertical flows into aquifer for varying initial water table position on the Cambay-Thasra section in the MRBC area. 


\section{Discussion}

Seepage losses from canals are a significant source of aquifer recharge. They are sensitive to the surface and subsurface conditions occurring in an irrigation project area. The purpose of this paper was to examine the influence of local conditions on recharge of deeper aquifers and assess their implications for conjunctive water use. For the study area, the scepage losses are most sensitive to the water table elevation. At the same location the losses can vary by a factor of seven depending on the water table position. Assuming the seepage losses to be proportional only to the wetted perimeter in the canal (Central Ground Water Board 1985) can lead to a gross misrepresentation of the available canal supplies.

For a given water table depth, the seepage losses from canals increase with the depth to the leaky layer above the aquifer. However, the total seepage flow from the canal does not recharge the aquifer. Its horizontal component flows out to drains and does not enter the aquifer. Only the vertical component can contribute to aquifer recharge. For a given canal size, this component is not very sensitive to the depth to the aquifer, if the water table depth is the same. It is also dependent on the distance from the centre of the canal to the boundary of the flow system.

The above studies have significant implications for the design of conjunctive use schemes in the irrigation project area. Since both surface features (canal length, cross section, location, drains etc.) and subsurface features (lithology, water table) vary over the area, conjunctive use schemes must be designed for integral units of the irrigation system, e.g. area commanded by a distributary. The operating depth to water table will need to be included as one of the main design variables of the conjunctive use scheme. The specific water table depth to be used will depend on the irrigation system, soils, subsurface conditions, crops and other related parameters. Considerable engineering and agronomic judgement will need to be exercised before deciding the design water table depth.

It must be noted, however, that the above studies dealt with only one component of aquifer recharge, seepage flows from irrigation canals. Recharge from rainfall and return flows from irrigated fields also contribute significantly to aquifer recharge. These components also interact with the surface and subsurface conditions of the area like seepage flows from canals. While they do not significantly alter the implications for conjunctive use in the area qualitatively, they must be included in specific designs of local conjunctive use schemes.

This work was carried out when the author was Visiting Commonwealth Academic Staff Fellow at the University of Birmingham, UK. The author is indebted to Prof. K R Rushton of the School of Civil Engineering of the University for his suggestions and interest.

\section{References}

Bouwer H 1969 Theory of seepage from open channels. Advances in hydroscience (ed.) V T Chow (New York: Academic Press) vol. 5

Central Ground Water Board 1985 Groundwater development in India. Ministry of Water Resources, Govt. of India, New Delhi 
Govt. of Gujarat 1975 Geology and groundwater resources in the MRBC area of Kaira district, with special reference to integrated development of surface and groundwater resources. Directorate of Groundwater Investigation, Govt. of Gujarat

Govt. of Gujarat 1985 Mahi Right Bank Canal Project. Report on the behaviour of subsoil water table 1983-84. Irrigation Department, Govt. of Gujarat

Govt. of India 1985 Seventh Five Year Plan, Planning Commission, Govt. of India, New Delhi

Rao N H, Sarma P B S 1988 Water resources utilization in a major irrigation project in India. Int. J. Water Res. Dev. 4: 200-207

Rushton K R 1989 Geohydrologic parameter estimation: pumping tests and tracer techniques. Proc. Int. Groundwater Conference, National Geophysical Research Institute, Hyderabad

Rushton K R, Redshaw S C 1979 Seepage and groundwater flow (New York: Wiley)

Sondhi S K, Rao N H, Sarma P B S 1989 Assessment of groundwater potential for a large irrigation project in India. J. Hydrol. 107: 283-295

Wachyan E, Rushton K R 1987 Water losses from irrigation canals. J. Hydrol. 92: 275-288

Water Technology Centre 1983 Resources inventory and plan for efficient use of water resources in Mahi Right Bank Canal Command Area. Water Technology Centre, Indian Agricultural Research Institute, New Delhi 